Hospital Practice

\title{
Abnormalities of thyroid function tests in hospital inpatients
}

\author{
M.C. Sheppard and D.B. Ramsden \\ Department of Medicine, University of Birmingham, Queen Elizabeth Hospital, Birmingham, B15 2TH, UK
}

\begin{abstract}
Summary: Results of thyroid function tests were analysed in 199 clinically euthyroid inpatients with normal serum thyroid stimulating hormone values. Serum total triiodothyronine was less than $1.25 \mathrm{nmol} / \mathrm{l}$ in $61.8 \%$ of samples, free triiodothyronine less than $3.9 \mathrm{pmol} / \mathbf{1}$ in $57.8 \%$, total thyroxine less than $63 \mathrm{nmol} / 1$ in $21.1 \%$ and free thyroxine less than $9.5 \mathrm{pmol} / 1$ in $17.6 \%$. In contrast, thyroxine binding globulin ratio was below normal $(<5)$ in only 5 samples. A significant positive correlation $(P<0.001)$ of serum free thyroxine with total thyroxine, thyroxine/thyroxine binding globulin ratio and free triiodothyronine was present as well as a significant negative correlation $(P<0.001)$ with serum thyroid stimulating hormone. There was no correlation of free thyroxine measurements with serum albumin or non-esterified fatty acid concentrations. Although serum free thyroxine is low in a number of patients with non-thyroidal illnesses, this does not appear to be due to a rise in non-esterified fatty acids or a fall in albumin as has been proposed. Serum thyroid stimulating hormone measurements are essential to confirm the diagnosis of hypothyroidism in such subjects.
\end{abstract}

\section{Introduction}

The clinical diagnosis of overt thyroid disease is confirmed by one or more of the standard tests of thyroid function such as free thyroxine index, thyroxine/thyroxine binding globulin ratio, free thyroxine assay and serum thyroid stimulating hormone concentration (Franklyn et al., 1984). The situation is considerably more complex in patients with a variety of non-thyroidal illnesses. A number of abnormalities of thyroid function tests are seen, amongst which a decrease in serum triiodothyronine and an increase in serum reverse triiodothyronine are the most common (Wartofsky \& Burman, 1982). In addition, in many seriously ill patients serum total thyroxine and free thyroxine index are low (Slag et al., 1981); serum free thyroxine as measured by equilibrium dialysis, however, is usually normal or even high (Wartofsky \& Burman, 1982; Spencer \& Nicoloff, 1981). Arising from these observations, therefore, are three important questions: (1) what are the mechanisms responsible for the various abnormalities seen in non-thyroidal illness? (2) are patients with non-thyroidal illness, whose serum thyroxine and triiodothyronine concentrations are low, truly hypothyroid and is there any place for thyroid hormone replacement? and (3) what are the thyroid function tests which should be used in

Correspondence: M.C. Sheppard, Ph.D., M.R.C.P. Accepted: 21 June 1985 clinical practice in the assessment of thyroid function in non-thyroidal illness?

Many previous studies of thyroid function in nonthyroidal illness have concentrated on small groups of severely ill patients. These observations may not be relevant to the assessment of thyroid status in hospital inpatients in general. In an attempt to clarify some of these problems we have measured a number of tests of thyroid function in a large unselected group of hospital inpatients and have subsequently analysed the proportion of clinically euthyroid patients with normal serum thyroid stimulating hormone values but abnormalities of standard thyroid function tests.

\section{Materials and methods}

A single blood sample was obtained from each of 208 inpatients of the general medical wards of the Queen Elizabeth Hospital, Birmingham. The primary diagnostic categories and numbers of patients in each group were as follows: liver disease (46), renal disease (39), cardiovascular disease (32), malignancy (30), endocrine/metabolic disease or diabetes mellitus (14), pulmonary disease (12), rheumatological disorders (11), central nervous system disorders (10), gastrointestinal bleeding (4) and miscellaneous (10).

Serum total thyroxine, total triiodothyronine, re- 
verse triiodothyronine and thyroglobulin were measured by radioimmunoassay (Black et al., 1975, 1981); thyroxine binding globulin, thyroxine binding prealbumin and albumin concentrations by immunoelectrophoresis (Bradwell et al., 1976); free thyroxine, free triiodothyronine and thyroid stimulating hormone concentrations by Amerlex kit assays (Amersham International plc, Buckinghamshire, UK). In the free hormone assays, free thyroid hormones and the modified labelled derivatives compete for binding to high-affinity anti-thyroxine or triiodothyronine antibodies. Non-esterified fatty acid concentrations were measured colorimetrically after conversion to chloroform-soluble copper salts in a kit assay (Boehringer, Mannheim).

Normal ranges (mean \pm standard deviations) for all tests were established from data collected from 200 fit, ambulant subjects in the West Midlands community who were not attending hospital or receiving any medication: total thyroxine $63-128 \mathrm{nmol} / 1$, total triiodothyronine $1.25-2.65 \mathrm{nmol} / \mathrm{l}$, reverse triiodothyronine $0.2-0.95 \mathrm{nmol} / \mathrm{l}$, free thyroxine $9.5-24.5$ $\mathrm{pmol} / \mathrm{l}$, free triiodothyronine $3.9-10.4 \mathrm{pmol} / 1$, thyroxine binding globulin $6.2-16.6 \mathrm{mg} / 1$, thyroxine binding prealbumin $200-450 \mathrm{mg} / \mathrm{l}$, albumin $34-51 \mathrm{~g} / \mathrm{l}$, thyroxine/thyroxine binding globulin ratio 5-13.4 and thyroid stimulating hormone less than $7.5 \mathrm{mU} / 1$.

\section{Results}

Five patients were found to have undiagnosed primary hypothyroidism and four to be thyrotoxic. All hypothyroid subjects had serum free thyroxine concentrations below $9.5 \mathrm{pmol} / 1$ and serum thyroid stimulating hormone greater than $7.5 \mathrm{mU} / \mathrm{l}$; the thyrotoxic subjects had thyroxine/thyroxine binding globulin ratio, free thyroxine and free triiodothyronine above the normal range. These individuals were excluded from further analysis of the data. The remaining patients under study comprised 107 females and 92 males with an age range of 12 to $85 \mathrm{y}$. Forty two per cent of subjects were over $60 \mathrm{y}$.

The previously reported abnormalities in thyroid function tests in apparently euthyroid subjects were confirmed in this study. Serum total triiodothyronine was less than $1.25 \mathrm{nmol} / 1$ in $61.8 \%$ of patients, free triiodothyronine less than $3.9 \mathrm{pmol} / 1$ in $57.8 \%$, reverse triiodothyronine greater than $0.95 \mathrm{nmol} / 1$ in $43.1 \%$, thyroxine binding prealbumin less than $200 \mathrm{mg} / 1$ in $49.7 \%$, and albumin less than $34 \mathrm{~g} / 1$ in $28.1 \%$.

The distribution of total thyroxine values is shown in Figure 1. Serum total thyroxine was less than $63 \mathrm{nmol} / 1$ in $21.1 \%$ of subjects and this increased to $43.2 \%$ of samples from those with renal disease. Serum concentration of free thyroxine was less than

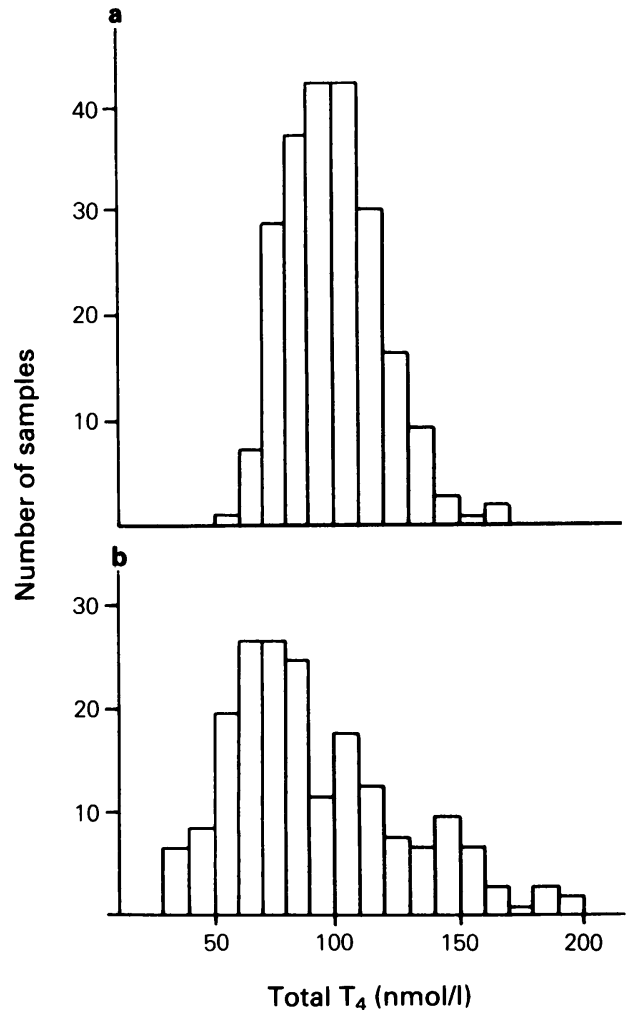

Figure 1 Distribution of serum total thyroxine $\left(T_{4}\right)$ measurements in 200 samples from control subjects (a) and 199 samples from patients with non-thyroidal illnesses (b).

$9.5 \mathrm{pmol} / 1$ in $17.6 \%$ of all patients (Figure 2) and $32.4 \%$ of samples from those with renal disease. Changes in total and free thyroxine measurements were thus very similar, as described previously (John \& Henley, 1983). In contrast, thyroxine/thyroxine binding globulin ratio was below normal (less than 5 ) in only 5 subjects. Serum total thyroxine concentrations were elevated (greater than $128 \mathrm{nmol} / \mathrm{l}$ ) in $16.6 \%$ of patients in whom total triiodothyronine was normal or reduced. Free thyroxine levels were elevated in only 3 subjects.

Serum non-esterified fatty acid concentrations were elevated (greater than $1 \mathrm{mEq} / \mathrm{l}$ ) in $13.4 \%$ of samples but the mean serum free thyroxine value $(11.0 \mathrm{pmol} / \mathrm{l})$ in this subset was not significantly different from the mean free thyroxine of the group as a whole (12.5 pmol/1). Kendall-Tau correlation analysis of the data in the hospitalized patients (Table I) showed significant positive correlation $(P<0.001)$ of serum free thyroxine with total thyroxine, thyroxine/thyroxine binding globulin ratio and free triiodothyronine and a significant negative correlation $(P<0.001)$ with 


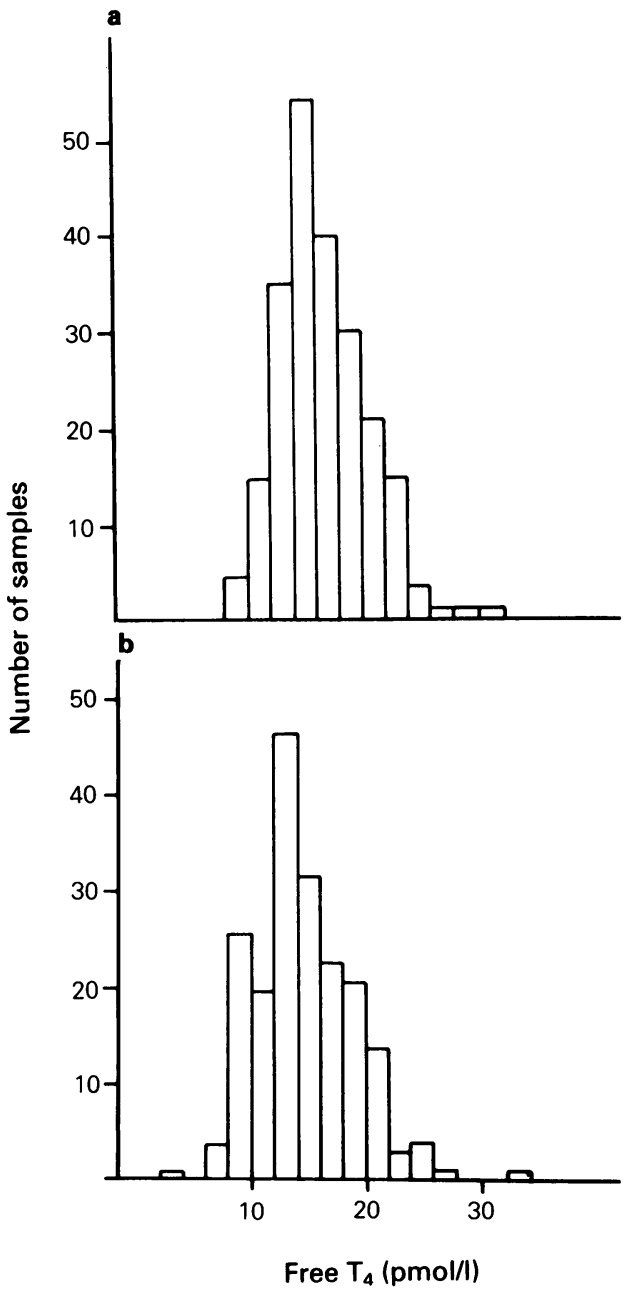

Figure 2 Distribution of serum free thyroxine $\left(T_{4}\right)$ measurements in 200 samples from control subjects (a) and 199 samples from patients with non-thyroidal illnesses (b).

Table I Correlations of free thyroxine values with other parameters of thyroid function. Kendall-Tau values

\begin{tabular}{ll}
\hline Total thyroxine & $0.394^{*}$ \\
Thyroxine binding globulin & $0.177^{*}$ \\
Thyroxine/thyroxine binding globulin & $0.325^{*}$ \\
Total triiodothyronine & 0.193 \\
Free triiodothyronine & $0.240^{*}$ \\
Thyroxine binding prealbumin & 0.117 \\
Albumin & 0.070 \\
Thyroid stimulating hormone & $-0.188^{*}$ \\
Non-esterified fatty acid & -0.029 \\
\hline
\end{tabular}

$n=195$ observations; ${ }^{*} P<0.001$ serum thyroid stimulating hormone. There was no correlation of free thyroxine with albumin or nonesterified fatty acid values. Serum thyroglobulin concentrations were elevated in $3.9 \%$ and undetectable (less than $1 \mu \mathrm{g} / \mathrm{l}$ ) in $22.2 \%$, contrasting with $15 \%$ of normal individuals with undetectable values.

\section{Discussion}

A fall in serum total and free triiodothyronine occurs in 50 to $70 \%$ of clinically euthyroid hospitalized patients (Wartofsky \& Burman, 1982; Utiger, 1980; Burger et al., 1976; Chopra et al., 1975) and constitutes the 'low $\mathrm{T}_{3}$ syndrome'. The serum concentration of reverse triiodothyronine is increased and these changes can be explained by a reduction in the activity of the $5^{\prime}$ deiodinase enzyme. The serum thyroxine may also be altered in such patients although daily production rate of thyroxine is claimed to be normal or only slightly decreased (Kaptein et al., 1982). The serum free thyroxine concentration measured by equilibrium dialysis is typically normal or high whereas the free thyroxine index gives subnormal values in many cases (Chopra et al., 1979b). A number of commercial kits for measuring free thyroxine have been introduced recently that are more convenient and less time-consuming than equilibrium dialysis and are clinically more useful and more accurate than the free thyroxine index or thyroxine/thyroxine binding globulin ratio (Franklyn et al., 1984; Chopra et al., 1980; Melmed et al., 1982; Wilke, 1982); these, however, yield results in non-thyroidal illness similar to the free thyroxine index (Amino et al., 1983). We have shown that $17.6 \%$ of a large group of hospital inpatients had subnormal free thyroxine values, a figure which increased to over $30 \%$ of patients with renal disease. The low free thyroxine does not appear to be due to a rise in nonesterified fatty acids or a fall in albumin as proposed in other studies (Ekins et al., 1983; Stockigt et al., 1983; Amino et al., 1983). A somewhat greater number of patients had low total thyroxine measurements and a further $16.6 \%$ had values above the normal range; the majority of these changes, however, appear to be related to alterations in thyroxine binding globulin concentration since thyroxine/thyroxine binding globulin ratio was invariably normal. The normal ratio in the vast majority of patients would argue against a significant role for a circulating inhibitor of thyroxine binding to its transport proteins (Chopra et al., 1979a).

Despite a marked lowering of serum triiodothyronine, patients with non-thyroidal illness appear to be clinically euthyroid. Achilles reflex time, pulse arrival time, basal metabolic rate and serum concentrations of creatine phosphokinase and cholesterol are normal (Chopra et al., 1974; Spector et al., 1976). It is possible 
that the duration of the fall in triiodothyronine is too short to allow the development of the clinical features of hypothyroidism, or the low serum triiodothyronine may have a protective role against excessive protein catabolism (Utiger, 1980); there is little evidence to support this hypothesis but at present it seems sensible to withhold hormone replacement therapy unless the diagnosis of hypothyroidism is clearly established. The significant negative correlation between free thyroxine and thyroid stimulating hormone in this study points to the possibility of mild primary thyroid dysfunction.

In patients with non-thyroidal illness the serum thyroid stimulating hormone concentration is characteristically in the normal range although modest elevations have been described in some individuals. Responses to thyrotrophin releasing hormone are usually normal but occasionally supranormal or subnormal (Chopra et al., 1974; Bermudez et al., 1975). It should be realised, however, that many factors, including high glucocorticoid levels and caloric deprivation,

\section{References}

AMINO, N., NISHI, K., NAKATANI, K., MIZUTA, H., ICHIHARA, K., TANIZAWA, O. \& MIYAI, K. (1983). Effect of albumin concentration on the assay of serum free thyroxin by equilibrium radioimmunoassay with labelled thyroxin analog (Amerlex free T4). Clinical Chemistry, 29, 321.

BERMUDEZ, F., SURKS, M.I. \& OPPENHEIMER, J.H. (1975). High incidence of decreased serum triiodothyronine concentration in patients with nonthyroidal disease. Journal of Clinical Endocrinology and Metabolism, 41, 27.

BLACK, E.G., GRIFFITHS, R.S., FINUCANE, J. \& HOFFENBERG, R. (1975). Radioimmunoassay of T3 and T4 in serum and urine. In Thyroid Hormone Metabolism, Harland, W.A. and Orr, J.S. (eds). p. 347. Academic Press: London.

BLACK, E.G., CASSONI, A., GIMLETTE, T.M.D., HARMER, C.L., MAISEY, M.N., OATES, G.D. \& HOFFENBERG, R. (1981). Serum thyroglobulin in thyroid cancer. Lancet, ii, 443.

BRADWELL, A.R., BURNETT, D., RAMSDEN, D.B., BURR, W.A., PRINCE, H.P. \& HOFFENBERG, R. (1976). Preparation of a monospecific antiserum to thyroxine binding globulin and its quantitation by rocket immunoelectrophoresis. Clinica Chimica Acta, 71, 501.

BURGER, A., NICOD, P., SUTER, P., VALLOTON, M.B., VAGENAKIS, A. \& BRAVERMAN, L. (1976). Reduced active thyroid hormone levels in acute illness. Lancet, i, 653.

CHOPRA, I.J., SOLOMON, D.H., CHOPRA, U., YOUNG, R.T. \& CHUA TECO, G.N. (1974). Alterations in circulating thyroid hormones and thyrotropin in hepatic cirrhosis: evidence for euthyroidism despite subnormal triiodothyronine. Journal of Clinical Endocrinology and Metabolism, $39,501$.

CHOPRA, I.J., CHOPRA, U., SMITH, S.R., RESA, M. \& SOLOMON, D.H. (1975). Reciprocal changes in serum which are accompaniments of severe illness, may impair thyroid stimulating hormone secretion (Morley, 1981) and thus a normal value may not always be an entirely reliable index for the euthyroid state.

In practical terms the interpretation of free thyroxine measurements in non-thyroidal illness is dependent on the patient population under study and the particular method of measurement. Present data would suggest a strategy of thyroxine/thyroxine binding globulin ratio or free thyroxine measurement followed, if low, by serum thyroid stimulating hormone assay.

\section{Acknowledgements}

We are grateful to Miss E. Wright, Mr A. Kapadi and Mr M. Crowe for technical assistance. MCS is in receipt of a Wellcome Trust Senior Lectureship. concentrations of 3,3',5'-triiodothyronine (reverse T3) and 3,3'5-triiodothyronine (T3) in systemic illness. Journal of Clinical Endocrinology and Metabolism, 41, 1043.

CHOPRA, I.J., CHUATECO, G.N., NGUYEN, A.H. SOLOMON, D.H. (1979a). In search of an inhibitor of thyroid hormone binding to serum proteins in nonthyroidal illnesses. Journal of Clinical Endocrinology and Metabolism, 49, 63.

CHOPRA, I.J., SOLOMON, D.H., HEPNER, G.W. \& MORGANSTEIN, A. (1979b). Misleadingly low free T4 index (FTI) and usefulness of reverse T3 (rT3) measurement in nonthyroid illnesses. Annals of Internal Medicine, 90, 905.

CHOPRA, I.J., VAN HERLE, A.J., CHUA TECO, G.N. \& NGUYEN, A.H. (1980). Serum free thyroxine in thyroidal and nonthyroidal illnesses. A comparison of measurements by radioimmunoassay, equilibrium dialysis and free thyroxine index. Journal of Clinical Endocrinology and Metabolism, 51, 135.

EKINS, R.P., JACKSON, T., EDWARDS, P., SALTER, C. \& OGIER, J. (1983). Euthyroid sick syndrome and free thyroxine assay. Lancet, ii, 402.

FRANKLYN, J.A., SHEPPARD, M.C., RAMSDEN, D.B., WILKINSON, R., \& HOFFENBERG, R. (1984). Measurement of free thyroxine and free triiodothyronine in thyrotoxicosis and hypothyroidism. Clinical Endocrinology (Oxford), 20, 107.

JOHN, R. \& HENLEY, R. (1983). Euthyroid sick syndrome and free thyroxine assay. Lancet, ii, 403.

KAPTEIN, E.M., ROBINSON, W.J., GRIEB, D.A.\& NICOLOFF, C J.T. (1982). Peripheral serum thyroxine, triiodothyronine and reverse triiodothyronine kinetics in the low thyroxine state of acute nonthyroidal illnesses. Journal of Clinical Investigation, 69, 526.

MELMED, S., GEDA, F.L., REED, A.W., PEKARY, A.E., PARK, J. \& HERSHMAN, J.M. (1982). A comparison of methods

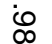

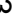


for assessing thyroid function in nonthyroid illness. Journal of Clinical Endocrinology and Metabolism, 54, 300.

MORLEY, J.E. (1981). Neuroendocrine control of thyrotropin secretion. Endocrine Reviews, 2, 396.

SLAG, M.F., MORLEY, J.E., ELSON, M.K., CROWSON, T.W., NUTTALL, F.Q. \& SHAFER, R.B. (1981). Hypothyroxinaemia in critically ill patients as a predictor of high mortality. Journal of the American Medical Association, 245, 43.

SPECTOR, D.A., DAVIS, P.J., HELDERMAN, H., BELL, B. \& UTIGER, R.D. (1976). Thyroid function and metabolic state in renal failure. Annals of Internal Medicine, 85, 724.

SPENCER, C.A. \& NICOLOFF, J.T. (1981). Free thyroxine estimates in nonthyroidal illness: comparison of eight methods. Journal of Clinical Endocrinology and Metabolism, 52, 1073.
STOCKIGT, J.R., STEVENS, V., WHITE, E.L. \& BARLOW, J.W. (1983). "Unbound analog" radioimmunoassays for free thyroxin measure the albumin-bound hormone fraction. Clinical Chemistry, 29, 1408.

UTIGER, R.D. (1980). Decreased extrathyroidal triiodothyronine production in nonthyroidal illness: benefit or harm? American Journal of Medicine, 69, 807.

WARTOFSKY, L. \& BURMAN, K.D. (1982). Alterations in thyroid function in patients with systemic illness: the “euthyroid sick syndrome". Endocrine Reviews, 3, 164.

WILKE, T.J. (1982). Five kits for estimating free thyroxine concentration in serum evaluated, and correlated with other indices to thyroid status. Clinical Chemistry, 28, 2051. 